\section{US picks 2 sites, Europe waits}

\section{Washington}

THE United States has selected two sites for its \$211 million gravity wave detector, a step that European scientists hope will encourage their governments to move ahead with plans for similar facilities.

Last week the National Science Foundation (NSF) announced that it has chosen Hanford, Washington, and Livingston, Louisiana, as twin sites for the Laser Interferometer Gravitational Wave Observatory (LIGO). The reality of gravity waves, essential consequences of Einstein's general theory of relativity, has so far not been directly demonstrated.

The US project, directed by Rochus (Robbie) Vogt of the California Institute of Technology, will consist of two detectors, each with twin 2.5-mile arms arranged at a 90 -degree angle. The sites are in rural and seismically stable areas, where development is unlikely, to reduce the chances that external vibrations will disturb the delicate instruments.

The Washington site, in the south-central part of the state, and the Louisiana site, 30 miles east of Baton Rouge, were judged the best of some two dozen potential sites scattered across the country. NSF director Walter Massey said that his criteria included accessibility, ease of land acquisition, and the promise of strong ties to local universities. The Hanford site is part of a vast government tract where nuclear fuel was first produced and where waste is now stored, while the Louisiana site is part of a private tract of forest, now being harvested for paper products, that will be deeded over to the government.

The United States is spending \$23 million this year to begin work on the two sites. The administration has asked Congress for $\$ 48$ million in fiscal year 1993 (which begins on 1 October 1992) to continue construction, which is expected to take five years. Vogt says the two sites will be built back-to-back so that the same team can be used to install the instrument, which at its core is a weight, hung at the end of a four-foot wide vacuum tubes, that is exposed to a continuous beam of laser light.

Vogt says that the US project can proceed without any help from the Europeans but that eventually a third and possibly a fourth site will be needed to perform the triangulation needed to pinpoint the celestial location of any waves that are detected. And he is optimistic that progress here will help his colleagues in the four countries - France, Italy, Germany and Britain - that have been asked to contribute to similar observatories in Europe.

"They are slaves to decisions in the US," says Vogt. "They are behind us now, but I think that they can catch up quickly once they get started."

The European projects have travelled along a rocky road since they were first proposed. The original plans were for a French-Italian collaboration, called Virgo, to be built near Pisa in northern Italy, and a German-British collaboration, called Geo, to be built near Hanover. But with six agencies - three in Germany alone being asked to contribute funds, progress has been slow.

Last fall Britain's Science and Engineering Research Council (SERC) took a decidedly hostile view of its proposed $\$ 10$ million contribution to the $\$ 90$ million project. Since then, physicists from the four countries have formed a more visible common front, called 'Eurograv', to promote the idea of a genuine European collaboration.

In the meantime, Virgo is moving ahead, says team leader Allain Brillet of the University of Paris at Orsay. Next month the group will present its final design proposal to a joint committee of the two funding agencies. A decision from them is expected in June, and funds for the project could be approved in the autumn

\section{Washington}

OfFICIALS from the United States, Germany and Russia meet today (27 February) in Bonn to flesh out last week's announcement that the three countries will create an international centre to support civilian research by Russian nuclear weapons scientists and engineers. There are as yet few details about the centre's structure, its methods of soliciting and selecting grants, the pool of eligible scientists or the type of work to be supported.

US government research agencies, including those from the National Science Foundation and the Energy Department, admit that so far they have played almost no role in the discussions. The first news of the centre came at a press conference on 17 February that followed a three-hour meeting in Moscow between US Secretary of State James Baker and Russian president Boris Yeltsin. Later that day their governments issued a joint statement with the German Foreign Minister, HansDietrich Genscher, who last month suggested some type of structure to support the estimated 2,000 or so scientists who occupy the top layer of the nuclear weapons complex of the former Soviet Union.

"It's not too early to ask these questions, but it's much too early to provide any answers," says a spokesman for the German embassy in Washington. "The first brainstorming will take place in Bonn."

This week's meeting provided the major donor countries with their first chance for release in January. Nearly 100 physicists and engineers are already at work on the project.

The outlook for the Geo project is somewhat less certain, admits team leader Karsten Danzmann of the Max Planck Institute for Quantum Optics in Garching. Last week a scientific panel on proposed large research projects submitted a report to Germany's research minister, Heinz Riesenhuber, that spoke favourably of the gravity wave detector but did not place it as one of the country's highest research priorities. Danzmann admits that German unification has put a heavy strain on his country's budget, and that Germany's existing commitments to other joint European projects, as with the proposed Large Hadron Collider at CERN, may require substantial new funding.

Danzmann nevertheless thinks that a European gravity wave detector is inevitable. "I'm convinced that money will be forthcoming in the next couple of years," he says. "Last year I would have said we'd be ready to start in a few months. Now it looks like it might be 1995 before everything falls into place."

Jeffrey Mervis

\title{
A way to wean weapons makers
}

to discuss the proposed centre. It will be followed by a larger meeting next month of all participating countries, and subsequent meetings as needed.

The United States has pledged \$25 million towards the centre, which will be staffed by science administrators from both donor countries and the Commonwealth of Independent States. At least twice that much is needed to operate the centre, however, with contributions expected from industry and private foundations as well as from national governments.

The new centre is intended to put the former Soviet scientists to work on a broad range of civilian projects covering both basic and applied research. "The whole point of this is to fund projects that have nothing to do with nuclear weapons," says a State Department official. Baker was bombarded with ideas during a recent visit to a formerly closed Soviet weapons facility, and scientists from the participating countries will also be encouraged to submit proposals for joint efforts with their Russian colleagues.

The centre is more likely to support proposals of limited scope and short duration than larger and more costly efforts with a timescale of five or ten years. "We want to support as many researchers as possible," says the State Department official, "as soon as possible." If all goes well, the centre could be up and running by the summer.

Jeffrey Mervis 